Received :2019-08-14 Revised :2019-09-2 Acceptance : 2019-20-05 Publish : 2019-12-31

\title{
THE EFFECTS OF THE UTILIZATION OF INTEGRATED MANAGEMENT POST OF MEDICAL FACULTY OF MULAWARMAN UNIVERSITY ON RISK INDICATORS OF NON-COMMUNICABLE DISEASE
}

\author{
Irma Kania Safitri ${ }^{1 *}$, Krispinus Duma ${ }^{2}$, Rahmat Bakhtiar ${ }^{3}$, Evi Fitriany ${ }^{4}$ \\ ${ }^{1}$ Medical Study Program, University of Mulawarman, Indonesia \\ 2,3,4 Public Health Sciences Laboratory, University of Mulawarman, Indonesia \\ *E-mail : irmakania.safitri@yahoo.com
}

\begin{abstract}
Non-communicable diseases have become a major public health problem in the last decade. In Indonesia, it was more than 36 million people dying from non-communicable diseases related to several risk factors including behavioral, metabolic and social risk factors. Several indicators can be considered to detect the risk factors of non-communicable diseases. They are blood pressure, cholesterol, glucose, uric acid, and body mass index. Efforts to prevent and control non-communicable diseases that are being developed in Indonesia are integrated management posts for non-communicable diseases that provide facilities and guidance to the community to take part in controlling the risk factors for noncommunicable diseases. This research is an observational analytic study with the cross-sectional method based on data obtained from the monitoring book of members of the Medical School of Mulawarman University. The sample of this study was all individuals in the population that met the inclusion criteria of the study. Sixty-five samples were obtained to see the posbindu effect on blood pressure and 61 samples saw the effect of posbindu on total cholesterol levels that met the inclusion criteria. The variables observed in this study were posbindu utilization, sample blood pressure, and total cholesterol levels in the sample. The results of the research, there was the effect of using posbindu on sample blood pressure $(\mathrm{p}=0.042)$, and there was no effect on the use of total cholesterol level in the sample $(\mathrm{p}=$ 0.590).
\end{abstract}

Keywords: Non-communicable diseases, Integrated Guidance Post, Cholesterol, Blood Pressure

\section{INTRODUCTION}

Non-communicable diseases (NCD), also referred to as chronic diseases or diseases related to lifestyle and that is not transmitted from person to person ${ }^{1}$. According to WHO in 2018 that non-communicable diseases cause 41 million deaths each year and around $71 \%$ of all deaths in the world are caused by NCD. There are four main types of NCD, namely heart disease (such as heart attacks and strokes), cancer, chronic respiratory diseases (asthma and chronic obstructive pulmonary disease), and diabetes ${ }^{2}$. The United States is one of the developed countries that are also not immune to the problem of CDM, even 7 outs of 10 deaths caused by NCD. In 2005, almost 1 out of 2 adults had at least one type of CDM and a quarter of NCD sufferers experienced 
disruption and limitations in their daily activities. This resulted in life expectancy in the United States is still below other developed countries ${ }^{3}$.

Based on data from the Indonesian Ministry of Health in 2014 that in Indonesia every year more than 36 million people died due to Non-Communicable Diseases (CDM) (63\% of all deaths). More than 9 million deaths due to non-communicable diseases occur before the age of 60, and $90 \%$ of these "early" deaths also occur in low and middle-income countries ${ }^{4}$. In 2018, Basic Health Research (Riskesdas) showed that there was an increase in the prevalence of several noncommunicable diseases compared to the results of Riskesdas in 2013. Stroke, for instance, an increase in stroke prevalence from 7 per mile in 2013 to 10.9 per mile, an increase in cancer prevalence from 1.4 per mile in 2013 to 1.8 per mile. Based on blood tests in the population under 15 years old, diabetes mellitus will be increased from $6.9 \%$ in 2013 to $8.5 \%$ in 2018 . The report also estimated an increase in the prevalence of hypertension based on the results of measurements in the population aged $\geq 18$ years from $25.8 \%$ in 2013 to $34.1 \%$ in $2018^{5}$.

In 2017, the Samarinda City Health Office reported that essential hypertension was the second highest with a total of 5582 patients, after acute nasopharyngeal infection. Diabetes mellitus was the next place with 1138 patients $^{6}$. The tendency of the increasing prevalence of NCD in the world community, including the people of Indonesia will have an impact on health, economy and national development efforts to prevent and control NCD. One of the efforts of the Indonesian government is developing the Integrated Development Post for non-communicable diseases (Posbindu NCD) ${ }^{1}$. Posbindu provides facilities and guidance to the public to participate in controlling risk factors for NCD. It includes the knowledge and skills to conduct early detection, monitoring of risk factors for non-communicable diseases as well as follow-up ${ }^{7}$.

The roles of Posbindu have paid attention to some researchers. Posbindu of the town of Kediri claimed that there was an influence on diet education and drug therapy on systolic blood pressure $^{8}$. The Ballaparang Public Health Center in Makassar, however, reported that of 100 participants only $23 \%$ of them used Posbindu NCD. ${ }^{9}$ Another study conducted in the Posbindu PTM area of Karanglo Village in Semarang City. The result was only $41.5 \%$ of respondents used Posbindu ${ }^{10}$.

Based on the background described above, the researcher is interested in examining the use of Posbindu activities by participants held at the Faculty of Medicine at Mulawarman University. Besides, the researcher wants to observe whether there is an effect on the indicators of noncommunicable diseases examined at Posbindu decreasing or staying within normal limits. For the reason, the researcher will do a study with the title of "The Effects of the Utilization of the Integrated Management Post of the Medical Faculty of Mulawarman University on Indicators of Risk of Non-communicable Diseases". 
Received :2019-08-14 Revised :2019-09-2 Acceptance : 2019-20-05 Publish : 2019-12-31

\section{MATERIAL AND METHOD}

This study is an analytic observational cross-sectional design. The aim is to observe the effect of the use of the posbindu program on blood pressure and total cholesterol levels of the posbindu participants. The population in this study is all the Posbindu NCD participants. The sample is all Posbindu NCD participants that match the inclusion and exclusion criteria the researcher wants.

A person is called a user if the person visits posbindu at least twice in the past year. The maximum range of attendance is six months. A person is not a user if the person visits posbindu twice with a range of attendance of more than six months. Blood pressure and total cholesterol levels are categorized as decreasing or staying within normal limits if after a previous visit blood pressure or total cholesterol levels are found to decrease or remain within normal limits. It is said to increase if the results of blood pressure or total cholesterol levels increase after a previous visit. Data analysis using the chi-square test.

\section{RESULT AND DISCUSSION}

The results of the study, 65 respondents met the inclusion criteria of the total number of 234 members of posbindu. The number of samples with a frequency of 2 visits has the highest number of 49 respondents $(75.4 \%)$. There are 10 respondents $(15.4 \%)$ with a frequency of 3 visits and six respondents $(9.2 \%)$ with 4 visits. This shows that the utilization of posbindu by registered participants is still low, as can be seen from the number of samples that have not been included yet reaching $50 \%$ of the total number of posbindu members. This also shows that the utilization of posbindu by selected respondents is still lacking because 51 of the 65 respondents present with a frequency of 2 times in one year, do not come every month.

Data shows 34 out of 65 respondents are women (52.3\%). Female respondents use Posbindu more because women have higher levels of concern than men, so women tend to pay more attention to their health conditions. In this study, the $\mathrm{p}$-value $=0.042$, this $\mathrm{p}$-value is smaller than $0.05(\mathrm{p}$ $<0.05)$. This means, statistically, it can be concluded that there is an effect of the use of posbindu on the blood pressure of posbindu participants who receive routine checks and education on every visit to posbindu. This research is similar to research conducted in the Posbindu City of Kediri. Blood pressure checks are done once in 1 week before dietary education and 4 times in 4 weeks after the education of the diet. The conclusion of the study, there is an influence on diet education and drug therapy on systolic blood pressure8. Changing one's lifestyle requires a process that is not easy because several factors are very influential, one of which is one's knowledge of the new object. Based on the information obtained, hypertension sufferers receive sufficient knowledge to reduce the risk of degenerative diseases, especially hypertension, and cardiovascular disease ${ }^{11}$. This increase in blood pressure, based on the results of other studies is also related to nutritional factors, psychological factors, physical activity factors and sleep quality ${ }^{12}$. Consumption of fruits and vegetables, according to the results of previous studies, is closely related to the incidence of hypertension because fruits and vegetables are rich in antioxidants, fiber, mineral potassium, and 
magnesium $^{12}$. High cholesterol or hypercholesterolemia in the blood also triggers hypertension. High cholesterol is a cause of blockages in peripheral blood vessels which reduce blood supply to the heart ${ }^{13}$.

The research conducted in Posbindu, obtained $\mathrm{p}$-value $=0.929$. This $\mathrm{p}$-value is greater than 0.05 ( $\mathrm{p}<0.05$ ). Therefore, statistically, the conclusion is that there is no significant relationship between total blood cholesterol levels and blood pressure. It is also similar to previous studies with pre-elderly respondents in the elderly posyandu (the center of integrated service). Using analysis with the Spearman Rank test, the p-value of 0.954 was obtained. Because the p-value is greater than 0.05 ( $p>0.05)$, the conclusion is that there is no relationship between cholesterol levels and blood pressure in pre-elderly hypertension. ${ }^{14}$

This research is to find the relationship between the effects of the use of posbindu on total cholesterol levels with 61 respondents. This is less than the respondents in the study looking for a relationship between the effects of using posbindu on blood pressure levels. Of the 65 people selected through a blood pressure check, only 61 people took an examination of total cholesterol levels. Thus, only 61 people responded to the inclusion criteria based on total cholesterol examination data.

The results show the value of $p=0.590$, the value of $p$ is greater than 0.05 ( $p>0.05)$. Statistically, the conclusion is that there is no effect of the use of posbindu on the cholesterol levels of posbindu participants who get routine checks and education on every visit to posbindu. This is different from other studies which concluded that there was a significant influence on the provision of nutritional counseling using the media and without the media. The counseling is carried out twice a week to reduce patients' blood cholesterol levels in the Banda Aceh City Health Center ${ }^{15}$.

Another study concluded that gender, IMT ???, systolic and diastolic blood pressure, and respondents who did not carry out heavy physical activities tended hypercholesteremia. Whereas consuming vegetables and fruits as well as smoking is concluded to not tend hypercholesteremia ${ }^{16}$. Being overweight means excess of various substances including blood cholesterol which can lead to the risk of coronary heart disease16. Similar results were shown by previous studies that increasing IMT is associated with increased levels of total cholesterol and triglycerides, lowering HDL cholesterol levels and increasing LDL cholesterol levels ${ }^{17}$.

\section{CONCLUSION}

Based on the results of the study, it can be concluded:

1. There is an effect between the management of the integrated training post (posbindu) Mulawarman University Faculty of Medicine on the blood pressure of respondents

2. There is no effect between the utilization of the integrated training post (posbindu) of the Medical Faculty of Mulawarman University on the total cholesterol level of the respondents. 


\section{REFERENCES}

1. Yandrizal, e. a. Petunjuk Operasional Pemberdayaan Pos Pembinaan Terpadu Penyakit Tidak Menular (POSBINDU PTM). Yogyakarta: Deepublish (2017).

2. WHO. Retrieved Oktober 10, 2018, from http://www.who.int/news-room/factsheets/detail/noncommunicable-diseases (2018).

3. Bustan, M. Manajemen Pengendalian Penyakit Tidak Menular. Jakarta: PT Rineka Cipta (2015).

4. Kementrian Kesehatan Republik Indonesia. Buku Pintar Posbindu Penyakit Tidak Menular. Jakarta: Kementrian Kesehatan Republik Indonesia (2014).

5. Kementrian Kesehatan Republik Indonesia. Riset Kesehatan Dasar; RISKESDAS. Jakarta: Balitbang Kementrian Kesehatan Republik Indonesia (2018).

6. Dinas Kesehatan Kota Samarinda. Laporan LB 1 Bulanan Puskesmas. Samarinda (2017).

7. Kementrian Kesehatan Republik Indonesia. Pedoman Umum Pos Pembinaan Terpadu Penyakit Tidak Menular. Jakarta: Kementrian Kesehatan Republik Indonesia (2014).

8. Nuridayanti, A., Nurul Makiyah, Rahmah. Pengaruh Edukasi Diet dan Terapi Obat terhadap Pengetahuan, Perilaku Diet dan Kepatuhan Minum Obat Penderita Hipertensi di Pos Pembinaan Terpadu Kelurahan Mojoroto Kota Kediri Jawa Timur. UMY Repository (2016).

9. Nazruddin, N. R. Faktor-Faktor Yang Mempengaruhi Pemanfaatan Pos Pembinaan Terpadu Penyakit Tidak Menular di Wilayah Kerja Puskesmas Ballaparang Kota Makassar. UIN Alaudin Reprository (2017).

10. Purdiyani, F. Pemanfaatan Pos Pembinaan Terpadu Penyakit Tidak Menular Oleh Wanita Lansia Dalam Rangka Mencegah Penyakit Tidak Menular di Wilayah Kerja Puskesmas Cilongok 1. Jurnal Kesehatan Masyarakat Universitas Diponegoro , 1 (4), 470-480 (2016).

11. Sutrisno. Pengaruh Edukasi Perawat Terhadap Tekanan Darah Pada Lansia Dengan Hipertensi. Universitas Muhammadiyah Yogyakarta Repository (2013).

12. Subekti, R.Y. Analisis Faktor- Faktor Yang Mempengaruhi Tekanan Darah Pada Usia Lanjut di Dusun Sumberan Sumber Agung Moyudan Sleman Yogyakarta. UNISA Digital Library-Reprository, 7-8 (2014).

13. Harefa, M. V. Hubungan Kadar Kolesterol Dengan Derajat Hipertensi Pada Penderita Hipertensi di wilayah Kerja Puskesmas Hiliweto Gido, Kabupaten Nias. Jurnal Universitas Sumatera Utara (2015).

14. Lestari, T. W. Hubungan Kadar Kolesterol dengan Tekanan Darah pada Pra Lansia Hipertensi di Posyandu Lansia Dusun Jetis Bantul Yogyakarta. UNISA Digital LibraryReprository (2015).

15. Rahmad, A. H. Pengaruh Pemberian Konseling Gizi terhadap Penurunan Kadar Kolesterol Darah. Jurnal Kesehatan Politeknik Kesehatan Tanjung Karang, 2 (9), 241 247 (2018).

16. Soleha, M. Kadar Kolesterol Tinggi dan Faktor-Faktor Yang Berpengaruh Terhadap Kolesterol Darah. Jurnal Biotek Medisiana Indonesia (2012).

17. Mawi, M. Indeks massa tubuh sebagai determinan penyakit jantung koroner pada orang dewasa berusia di atas 35 tahun. Jurnal Kedokteran Trisakti (2016). 